\title{
Diamino-ligated platinum(II) and platinum(IV) phenoxide complexes; syntheses and crystal structures
}

\author{
Gerardus M. Kapteijn ", Michel D. Meijer ", David M. Grove a, Nora Veldman ${ }^{\text {b }}$, \\ Anthony L. Spek ${ }^{\text {b. }}$, Gerard van Koten ${ }^{\text {a.* }}$ \\ "Debye Research Instihute, Department of Metal-Mediated Synthesis, Utrecht University. Padualaun 8. 3584 CH Utrecht, Netherlands

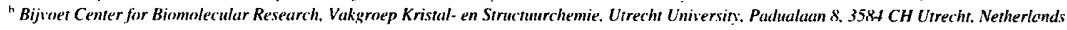

Received 28 February 1997: accepted 28 May 1997

\begin{abstract}
The reaction of the diamino-ligated dimethylplatinum( II) complex $\left[\mathrm{Pt}(\mathrm{Me})_{2}(\right.$ bpy $\left.)\right]$ (bpy $=2.2^{\prime}$-bipyridyl) with phenol affords the new complex $[\mathrm{Pt}(\mathrm{Me})(\mathrm{OPh})(\mathrm{bpy})]$ (1). The X-ray crystal structure of square-planar 1 is reported: orthorhombic. space group $P 2_{1} 2,2_{1}$, (No. 19), $a=9.1625$ ( 12$), b=12.3922(12), c=13.3181$ (13) $\hat{A}, Z=4$. Reaction of complex 1 with Mel or benzyl bromide affords the novel sixcoordinate platinum (IV) aryloxide complexes [ $\left.\mathrm{Pt}(\mathrm{Me})_{2}(\mathrm{I})(\mathrm{OPh})(\mathrm{bpy})\right]$ (2) and $\left[\mathrm{Pt}(\mathrm{Me})\left(\mathrm{CH}_{2} \mathrm{Ph}\right)(\mathrm{Br})(\mathrm{OPh})(\mathrm{bpy})\right]$ (3), respectively. The X-ray crystal structure of octahedral 2 is reported: monoclinic, space group $P Z_{1} / c($ No. 14$), a=10.0194(6), b=10.5126(10)$. $c=17.6596(14) \AA . . \beta=104.159(6)^{\circ} . Z=4$. The iodide complex 2 exists as a mixture of two isomers in solution (the major one corresponds to that of trans oxidative addition), whereas the bromide complex 3 is found only as the trans oxidative addition product. C 1997 Elsevier Science S.A.
\end{abstract}

Kewwords: Organoplatinum complexes: Phenoxide complexes; Bipyridyl complexes; Oxidative addition: Crystal structures

\section{Introduction}

The chemistry of late transition metal alkoxide complexes has been the subject of a number of reviews [1] and this area still attracts much attention. One reason for this continuing interest is that such complexes have been postulated as key intermediates in various transition metal-catalysed processes $\{2\}$. An eariter belief that the metal-to-oxygen bond is weak. as a result of the occurrence of antibonding $\pi$-interactions between filled metal d-orbitals and oxygen lone pairs [3], may have limited research in this area and reports concerning late transition metal alkoxides and aryloxides are still rare. in particular when the other ligands are mono- or bidentate tertiary amines. It is now recognised, however, that the metalto-oxygen bond may be of comparable strength or even stronger than the metal-to-carbon $\left(\mathrm{sp}^{3}\right.$ ) bond [4]. Reported interesting properties of late transition metal alkoxides include insertion of small molecules into the metal-to-oxygen bond $[5]$, and their ability to associate with alcohols, and so form adducts, through $\mathrm{O}-\mathrm{H} \cdots \mathrm{O}$ hydrogen bonding $[6]$.

\footnotetext{
* Corresponding author. Tel.: 3130 2533120; fax: 3130 2523615: e-mail: vankoten@xray.chem.ruu.nl

${ }^{1}$ Corresponding author regarding crystallographic studies.
}

As part of our study of alkoxo and aryloxo $\mathrm{N}$-ligated palladium (II) complexes of the type $\left[\mathrm{Pd}(\mathrm{OR})_{2}(\mathrm{~N} \sim \mathrm{N})\right]$ [7] and $[\mathrm{Pd}(\mathrm{OR})(\mathrm{Me})(\mathrm{N} \sim \mathrm{N})][8](\mathrm{N} \sim \mathrm{N}=$ diamine ligand $)$ we report here the synthesis, characterisation and properties of organoplatinum( II) and organoplatinum(IV) aryloxide complexes containing 2.2'-bipyridyl ( = bpy) as the bidentate $\mathrm{N}$-donor ligand.

\section{Experimental}

\subsection{General considerations}

Reactions were performed in an atmosphere of nitrogen using standard Schlenk techniques. Benzene, diethyl ether and pentane were freshly distilled from sodium benzophenone-ketyl. All other solvents were used as received. The solvents acetone (p.a), dimethyl sulfoxide (DMSO) ard the materials 2.2'-bipyridyl (bpy), phenol and Celite ( filter aid) were purchased from Janssen Chimica. The complex [ $\mathrm{Pt}(\mathrm{Me})_{2}$ (bpy)] was prepared according to a literature procedure [9]. ${ }^{1} \mathrm{H}(300.13 \mathrm{MHz})$ and ${ }^{13} \mathrm{C}(75.03 \mathrm{MHz}) \mathrm{NMR}$ spectra were recorded on a Bruker AC 300 spectrometer at ambient temperature in deuterated solvents $\left(\mathrm{CDCl}_{3}\right.$, 
DMSO- $d_{6}$ and acetone- $d_{6}$ ) obtained from ISOTEC Inc. Elemental analyses were carried out by Domis und Kolbe. Mikroanalytisches Laboratorium. Mülheim a.d. Ruhr. Germany.

\subsection{Preparation of $[\operatorname{Pt}(\mathrm{Me})(\mathrm{OPh})(\mathrm{bpy})](\mathrm{I})$}

Phenol ( $4.84 \mathrm{~g} .51 .4 \mathrm{mmol})$ was added to a stirred suspension of $\left[\mathrm{Pt}(\mathrm{Me})_{2}(\mathrm{bpy})\right](1.96 \mathrm{~g} .5 .1 \mathrm{mmol})$ in benzene $(30 \mathrm{ml})$. The resulting red suspension was stirred for $1 \mathrm{~h}$. after which a yellow precipitate (phenol adduct) was isolated by centrifugation. This residue was washed twice with pentane $(2 \times 25 \mathrm{ml})$ and $\mathrm{Et}_{2} \mathrm{O}(15 \mathrm{ml})$, to afford product 1 as an orange solid. Orange crystals of 1 suitable for X-ray diffraction can be obtained by cooling a saturated acetone solution to $-20^{\circ} \mathrm{C}$. Yield $2.10 \mathrm{~g}(89 \%)$.

'H NMR (acetone- $\left.\mathrm{d}_{6}\right), \delta: 9.23\left(\mathrm{~d}, 1 \mathrm{H},{ }^{3} J(\mathrm{HH})=5.8 \mathrm{~Hz}\right.$. with platinum satellites $\left.{ }^{3} \mathrm{~J}(\mathrm{PtH})=52.0 \mathrm{~Hz} . \mathrm{H}_{6}\right), 8.95(\mathrm{~d}, \mathrm{IH}$, ${ }^{3} J(\mathrm{HH})=5.4 \mathrm{~Hz}$. with platinum satellites ${ }^{3} J(\mathrm{PtH})=8.3 \mathrm{~Hz}$, $\left.\mathrm{H}_{6}{ }^{\prime}\right), 8.53-8.28\left(\mathrm{~m}, 4 \mathrm{H}, \mathrm{H}_{3}, \mathrm{H}_{3}{ }^{\prime}, \mathrm{H}_{5}, \mathrm{H}_{5}{ }^{\prime}\right), 7.80$ (td, $\mathrm{lH}$, $\left.{ }^{3} J(\mathrm{HH})=6.6 \mathrm{~Hz},{ }^{4} J(\mathrm{HH})=1.1 \mathrm{~Hz}, \mathrm{H}_{4}\right), 7.64(\mathrm{td}, 1 \mathrm{H}$, $\left.{ }^{3} J(\mathrm{HH})=6.5 \mathrm{~Hz},{ }^{4} J(\mathrm{HH})=1.7 \mathrm{~Hz}, \mathrm{H}_{4}{ }^{\prime}\right), 6.97(\mathrm{~d}, 2 \mathrm{H}$. $\left.{ }^{3} J(\mathrm{HH})=7.4 \mathrm{~Hz}, m-\mathrm{H} \mathrm{Ar}\right), 6.90\left(\mathrm{td}, 2 \mathrm{H},{ }^{3} J(\mathrm{HH})=7.7 \mathrm{~Hz}\right.$, $\left.{ }^{4} J(\mathrm{HH})=2.0 \mathrm{~Hz}, o-\mathrm{H} \mathrm{Ar}\right) .6 .34\left(\mathrm{tt}, 1 \mathrm{H},{ }^{3} J(\mathrm{HH})=7.0 \mathrm{~Hz}\right.$, $+J(\mathrm{HH})=1.3 \mathrm{~Hz}, p-\mathrm{H} \mathrm{Ar}$ ), 1.06 (s. $3 \mathrm{H}$, with platinum satellites ${ }^{2} J(\mathrm{PtH})=82.7 \mathrm{~Hz}$, P(Me). Anal. Calc. for $\mathrm{C}_{17} \mathrm{H}_{16} \mathrm{~N}_{2} \mathrm{OPt}$ C. 44.44 ; H. 3.51; N. 6.10. Found: $\mathrm{C}, 44.31$ : H. 3.54: N. $6.04 \%$.

\subsection{Preparation of $[\mathrm{Pt} / \mathrm{Me})_{2}(I)(\mathrm{OPh})(\mathrm{bp} y) /(2)$}

To a solution of $[\mathrm{Pt}(\mathrm{Me})(\mathrm{OPh})$ (bpy) ] (1) (1.96 g. 5.1 $\mathrm{mmol})$ in acetone $(40 \mathrm{ml})$ was added an excess of freshly distilled Mel ( $3.5 \mathrm{ml}, 13.6 \mathrm{mmol}$ ). Traces of insoluble impurities that may have formed at this point were filtered off. The clear solution was then allowed to stand undisturbed for 48 $\mathrm{h}$ and during this time large yellow block-shaped crystals (suitable for X-ray diffraction) formed. The crystals were collected by filtration, washed with pentane $(2 \times 10 \mathrm{ml})$, and then dried in vacuo. Yield $0.96 \mathrm{~g}(87 \%)$. In solution the complex is present as two isomers indicated here as the major $(60 \%)$ and minor ( $40 \%$ ) isomers ( see Section 3 ).

${ }^{\prime} \mathrm{H}$ NMR (DMSO-d $\left.\mathrm{d}_{6}\right), \delta: 9.22-9.18\left(\mathrm{~m}, 1 \mathrm{H}, \mathrm{H}_{6}\right.$ $($ major + minor $)), 8.90\left(\mathrm{~d}, 1 \mathrm{H},{ }^{3} \mathrm{~J}(\mathrm{HH})=8.5 \mathrm{~Hz}, \mathrm{H}_{6}{ }^{\prime}\right.$ (major + minor)), $8.82\left(\mathrm{~m}, 2 \mathrm{H}, \mathrm{H}_{3}\right.$ and $\mathrm{H}_{3}{ }^{\prime}$ (major + minor) ), $8.47\left(\mathrm{~m}, 2 \mathrm{H}, \mathrm{H}_{5}\right.$ and $\mathrm{H}_{\mathrm{s}^{\prime}}$ (major + minor)), 8.33 (td, $0.4 \mathrm{H},{ }^{3} J(\mathrm{HH})=6.1 \mathrm{~Hz},{ }^{4} J(\mathrm{HH})=2.0 \mathrm{~Hz}, \mathrm{H}_{4}$ (minor)), $8.05\left(\right.$ td, $0.6 \mathrm{H},{ }^{3} J(\mathrm{HH})=6.2 \mathrm{~Hz},{ }^{4} J(\mathrm{HH})=2.0 \mathrm{~Hz}, \mathrm{H}_{4}$ (major)), $7.88\left(\right.$ td, $0.4 \mathrm{H},{ }^{3} J(\mathrm{HH})=6.1 \mathrm{~Hz},{ }^{4} J(\mathrm{HH})=1.2$ $\mathrm{Hz} . \mathrm{H}_{4}{ }^{\prime}$ (minor)), 7.80 (td, $0.6 \mathrm{H},{ }^{3} J(\mathrm{HH})=6.1 \mathrm{~Hz}$, ${ }^{4} J(\mathrm{HH})=1.2 \mathrm{~Hz}, \mathrm{H}_{4}^{\prime}$ (major) ). $7.06(\mathrm{~m}, 4 \mathrm{H}, o, m-\mathrm{H} \mathrm{Ar}$ (major+minor)), 6.93 (tt. $0.4 \mathrm{H} .{ }^{3} J(\mathrm{HH})=7.3 \mathrm{~Hz}$, ${ }^{4} J(\mathrm{HH})=1.4 \mathrm{~Hz}, p-\mathrm{H}$ Ar (minor)), 6.71 (tt. $0.6 \mathrm{H}$. ${ }^{3} J(\mathrm{HH})=7.0 \mathrm{~Hz},{ }^{4} J(\mathrm{HH})=1.5 \mathrm{~Hz}, p-\mathrm{H} \mathrm{Ar}($ major $\left.)\right) .1 .77$ (s, $1.8 \mathrm{H}$, with platinum satellites $2 J(\mathrm{PtH})=70.3 \mathrm{~Hz}, \mathrm{PtMe}_{\mathrm{cy}}$ (major)), 1.63 (s, 1.2H, with platinum satellites ${ }^{2} J(\mathrm{PtH})=67.1 \mathrm{~Hz}, \mathrm{PtMe}_{\mathrm{cq}}$ (minor)), 1.38 ( $\mathrm{s}, 1.8 \mathrm{H}$. with platinum satellites ${ }^{2} J(\mathrm{PtH})=69.4 \mathrm{~Hz}, \mathrm{PtMe}_{\text {ax }}$ (major)), $1.28\left(\mathrm{~s}, 1.2 \mathrm{H}\right.$, with platinum satellites ${ }^{2} J(\mathrm{PtH})=77.0 \mathrm{~Hz}$, $\mathrm{PtMe}_{\mathrm{ix}}$ (minor)). Anal. Calc. for $\mathrm{C}_{: 8} \mathrm{H}_{19} \mathrm{IN}_{2} \mathrm{OPt}$ C, 36.01; H. 3.24: N, 4.69. Found: C. 35.95; H, 3.18; N, 4.66\%.

\subsection{Preparation of $\left[\mathrm{Pr}^{\prime \prime}(\mathrm{Me})\left(\mathrm{CH}_{2} \mathrm{Ph}\right)(\mathrm{Br})(\mathrm{OPh})(\mathrm{bpy}) /(3)\right.$}

To a solution of [ $\mathrm{Pt}(\mathrm{Me})(\mathrm{OPh})(\mathrm{bpy})]$ ( 1 ) $(0.35 \mathrm{~g}, 0.92$ $\mathrm{mmol})$ in acetone $(20 \mathrm{ml})$ was added an excess of freshly distilled benzyl bromide $(1.0 \mathrm{ml})$. Traces of insoluble impurities that may have formed at this point were filtered off. The clear solution was then allowed to stand undisturbed for 48 h, during which time large yellow block-shaped crystals formed. The crystals so produced were collected by filtration. washed with pentane $(2 \times 10 \mathrm{ml})$, and then dried in vacuo. Yield $0.41 \mathrm{~g}(81 \%)$.

${ }^{1} \mathrm{H}$ NMR (DMSO- $\left.\mathrm{d}_{6}\right), \delta: 8.88\left(\mathrm{~d}, 1 \mathrm{H},{ }^{3} J(\mathrm{HH})=4.1 \mathrm{~Hz}\right.$, with platinum satellites $\left.{ }^{3} J(\mathrm{PtH})=163.2 \mathrm{~Hz}, \mathrm{H}_{\mathrm{f}}\right), 8.75$ (d, $1 \mathrm{H},{ }^{3} J(\mathrm{HH})=5.4 \mathrm{~Hz}$. with platinum satellites $\left.{ }^{3} J(\mathrm{PtH})=40.1 \mathrm{~Hz}, \mathrm{H}_{6}{ }^{\prime}\right), 8.52\left(\mathrm{~d}, 1 \mathrm{H},{ }^{3} \mathrm{~J}(\mathrm{HH})=8.1 \mathrm{~Hz}\right.$. $\left.\mathrm{H}_{3}\right) .8 .48$ (d. $\left.1 \mathrm{H},{ }^{3} J(\mathrm{HH})=8.2 \mathrm{~Hz}, \mathrm{H}_{3}{ }^{\prime}\right), 8.24$ (td, $2 \mathrm{H}$. $\left.{ }^{3} J(\mathrm{HH})=8.7 \mathrm{~Hz},{ }^{+} J(\mathrm{HH})=1.6, \mathrm{H}_{5}, \mathrm{H}_{5}{ }^{\prime}\right), 7.84(\mathrm{~d}, \mathrm{IH}$, $\left.{ }^{3} J(\mathrm{HH})=6.6 \mathrm{~Hz}, \mathrm{H}_{4}\right), 7.70\left(\mathrm{dt} .1 \mathrm{H} .{ }^{3} J(\mathrm{HH})=8.1 \mathrm{~Hz}\right.$, $\left.{ }^{4} J(\mathrm{HH})=1.1 \mathrm{~Hz}, \mathrm{H}_{4}{ }^{\prime}\right), 7.23\left(\mathrm{~d}, 2 \mathrm{H},{ }^{3} J(\mathrm{HH})=7.6 \mathrm{~Hz}, 0 \cdot \mathrm{H}\right.$ OAr), 7.05 (d. $\left.1 \mathrm{H},{ }^{3} \mathrm{~J}(\mathrm{HH})=7.4 \mathrm{~Hz}, m-\mathrm{H} \mathrm{OAr}\right), 6.86(\mathrm{t}$. IH. $\left.{ }^{3} J(\mathrm{HH})=7.4 \mathrm{~Hz}, p-\mathrm{H} \mathrm{Bz}\right), 6.71\left(\mathrm{t}, 1 \mathrm{H} .{ }^{3} J(\mathrm{HH})=7.2\right.$ Hz. $p$-HOAr $), 6.64\left(\mathrm{~d}, 2 \mathrm{H},{ }^{3} J(\mathrm{HH})=7.7 \mathrm{~Hz}, m-\mathrm{HBz}\right), 6.44$ (d. $2 \mathrm{H},{ }^{3} J(\mathrm{HH})=7.2 \mathrm{~Hz}, \quad o-\mathrm{H} \quad \mathrm{Bz}$ ), 3.83 (d. IH, ${ }^{2} J(\mathrm{H}, \mathrm{H})=8.2 \mathrm{~Hz}$, with platinum satellites ${ }^{2} J(\mathrm{PtH})=102.9$ $\left.\mathrm{Hz}, \mathrm{CH}_{2} \mathrm{Ph}\right), 3.38$ (d. $1 \mathrm{H} .{ }^{2} \mathrm{~J}(\mathrm{HH})=8.2 \mathrm{~Hz}$, with platinum satellites $\left.{ }^{2} J(\mathrm{PtH})=74.0 \mathrm{~Hz}, \mathrm{CH}_{2} \mathrm{Ph}\right), 1.73(\mathrm{~s}, 3 \mathrm{H}$, with platinum satellites ${ }^{2} J(\mathrm{PtH})=69.4 \mathrm{~Hz}$. PtMe $)$. Anal. Calc. for $\mathrm{C}_{24} \mathrm{H}_{23} \mathrm{BrN}_{2} \mathrm{OPt}: \mathrm{C}, 45.72: \mathrm{H}, 3.68: \mathrm{N}, 4$.44. Found: $\mathrm{C}, 45.55$; H. 3.82; N, $4.38 \%$.

\subsection{Structure determination and refinement of 1}

An orange transparent crystal $(0.12 \times 0.15 \times 0.45 \mathrm{~mm}$, covered in inert oil) was mounted on top of a Lindemannglass capillary and transferred into the cold nitrogen stream of an Enraf-Nonius CAD4-Turbo diffractometer on a rotating anode. Lattice parameters were determined by least-squares treatment, using the setting angles (SET4) [10] of 25 wellcentered reflections in the range $11.5<\theta<13.9^{\circ}$. The unit cell parameters were checked for the presence of higher lattice symmetry [1I]. Crystal data and details on data collection and refinement are collected in Table 1. Data were corrected for Lp effects and for a linear decay of $7 \%$ of the periodically measured reference reflections. A face-indexed analytical absorption correction |12| was applied (as implemented in PLATON) [13]. The structure was solved by automated Patterson methods and subsequent difference Fourier techniques (DIRDIF-92) [14]. Refinement on $F^{2}$ was carried out by full-matrix least-squares techniques (SHELXL-93) [15]. The hydrogen atoms were refined with a fixed isotropic thermal parameter of their carrier atoms by a factor of 1.5 for 
Table ]

Crystallographic data for 1 and 2 *

\begin{tabular}{|c|c|c|}
\hline & 1 & 2 \\
\hline \multicolumn{3}{|l|}{ Crystal data } \\
\hline Formula & $\mathrm{C}_{17} \mathrm{H}_{16} \mathrm{~N}_{2} \mathrm{OPt}$ & $\mathrm{C}_{1 \mathrm{k}} \mathrm{H}_{1,} \mathrm{IN} \mathrm{N}_{2} \mathrm{OPt}$ \\
\hline Formula weight & 459.41 & 601.35 \\
\hline Crystal system & orthorhombic & monoclinic \\
\hline Space group & $P 2,2,2$, (No. 19) & $P 2, / c($ No. 14$)$ \\
\hline$a(\AA)$ & $9.1625(12)$ & {$[0.0194(6)$} \\
\hline$b(\AA ̊)$ & $12.3922(12)$ & $10.5126(10)$ \\
\hline$c(\AA)$ & $13.3181(13)$ & $17.6596(14)$ \\
\hline$\beta\left(^{\circ}\right)$ & & $104.159(6)$ \\
\hline$V\left(\AA^{3}\right)$ & $1512.2(3)$ & $1803.6(3)$ \\
\hline$D_{\text {call }}\left(\mathrm{g} \mathrm{cm}^{-1}\right)$ & 2.018 & 2.215 \\
\hline$Z$ & 4 & 4 \\
\hline$F(000)$, electrons & 872 & 1120 \\
\hline$\mu_{\text {cali }}\left(\mathrm{cm}^{-1}\right)(\operatorname{Mo~K} \alpha)$ & 92.8 & 95.0 \\
\hline Crystal size $(\mathrm{mm})$; colour & $0.12 \times 0.15 \times 0.45 ;$ orange & $0.05 \times 0.18 \times 0.43$; yellow \\
\hline \multicolumn{3}{|l|}{ Data collection and refinement } \\
\hline$T(\mathrm{~K})$ & 150 & 150 \\
\hline$\theta_{\operatorname{man}}, \theta_{\max }\left({ }^{\circ}\right)$ & 2.2 .27 .5 & $2.1,27.5$ \\
\hline Wavelength $(\AA \AA)$ & 0.71073 (graphite monochr.) & 0.71073 (graphite monochr.) \\
\hline Scan type & $\omega$ & $\omega$ \\
\hline $\mathrm{X}$-ray exposure time $(\mathrm{h})$ & 12.8 & 7.2 \\
\hline Linear decay $(\%)$ & 7 & 4 \\
\hline Reference reflections & $2-20 .-20-5,-24-2$ & $22-4,322.412$ \\
\hline Data set & $0: 11:-16: 16:-14: 17$ & $0: 12 ; 0: 13,-22: 22$ \\
\hline Total data & 6390 & 4310 \\
\hline Total unique data & 3472 & 4083 \\
\hline Transmission correction: $\min ., \max$. & 0.16 .0 .46 & $0.19,0.55$ \\
\hline Final $R 1^{\text {a }}$ & 0.0310 for $3186(I>2 \sigma(t))$ & 0.036 for $3165(I>2 \sigma(I))$ \\
\hline Final $w R 2^{b}$ & 0.0534 ( 3472 data) & 0.0858 ( 4083 data) \\
\hline Goodness of fit & 1.06 & 1.04 \\
\hline$w^{-1}$ & $\sigma^{2}\left(F^{2}\right)+(0.0088 P)^{2}$ & $\sigma^{2}\left(F^{2}\right)+(6.0368 P)^{2}+6.27 P$ \\
\hline$(\Delta / \sigma)_{\max }$ & 0.001 & 0.001 \\
\hline Min., max. residual density $\left(\mathrm{e} \AA^{-3}\right.$ ) & $-0.83,1.36$ & -1.30 .2 .12 (near Pt) \\
\hline
\end{tabular}

${ }^{3} R\left|=\sum\right|\left|F_{\mathrm{o}}\right|-\left|F_{\mathrm{c}}\right|\left|/ \sum\right| F_{\mathrm{d}} \mid$.

$\left.{ }^{n} w R 2=\left|\sum\left[w^{2}\left(F_{w}{ }^{2}-F_{v}{ }^{2}\right)^{2}\right] / \Sigma\right| w\left(F_{w}{ }^{2}\right)^{2}\right]^{1 / 2}$.

' $P=\left(\max \left(F_{\mathrm{u}}{ }^{2}, 0\right)+2 F_{\mathrm{c}}{ }^{2}\right) / 3$.

the methyl hydrogen atoms and a factor of 1.2 for the aryl hydrogen atoms. All non-hydrogen atoms were refined with anisotropic thermal parameters. A minor orientational disorder of the complete molecule was found. This was taken into account with a $0.985: 0.015$ disorder model for the platinum positions $\mathrm{Pt}(1)$ and $\mathrm{Pt}(2)$. Refinement of a racemic twin model resulted in better $w R 2$ values and a component ratio of $0.470(16): 0.530$. Weights were optimised in the final refinement cycles. Final refined atomic coordinates and equivalent isotropic thermal parameters for 1 ase listed in Table 2.

\subsection{Structure determination and refinement of 2}

A yellow crystal $(0.05 \times 0.18 \times 0.43 \mathrm{~mm}$, covered in inert oil), was mounted on top of a Lindemann-glass capillary and transferred into the cold nitrogen stream of an Enraf-Nonius CAD4 diffractometer on a rotating anode. Lattice parameters were determined by least-squares treatment, using the setting angles (SET4) [10] of 25 well-centered reflections in the range $9.8<\theta<13.9^{\circ}$. The unit cell parameters were checked for the presence of higher lattice symmetry [ 11] . Crystal data and details on data collection and refinement are collected in Table 1. Data were corrected for Lp effects and for a linear decay of $4 \%$ of the periodically measured intensity control reflections. A face-indexed analytical absorption correction was applied (as implemented in PLATON) [13]. The structure was solved by automated Patterson methods and subsequent difference Fourier techniques (DIRDIF-92) [14]. Refinement on $F^{2}$ was carried out by full-matrix least-squares techniques (SHELXL-93) [15]. The hydrogen atoms were refined with a fixed isotropic thermal parameter of their carrier atoms by a factor of 1.5 for the methyl hydrogen atoms and a factor of 1.2 for the aryl hydrogen atoms. All nonhydrogen atoms were refined with anisotropic thermal parameters. Neutral atom scattering factors were taken from International Tables for Crystallography [16]. Geometrical calculations and illustrations were performed with PLATON 
Table 2

Final coordinates and equivalent isotropic thermal parameters of the nonhydrogen atoms for 1

\begin{tabular}{|c|c|c|c|c|}
\hline Atom & $x$ & $y$ & $=$ & $U_{c u t}=\left(\mathrm{A}^{2}\right)$ \\
\hline${ }^{*} \operatorname{Pt}(1)^{n}$ & $0.19431(3)$ & $0.15967(2)$ & $0.15534(2)$ & $0.0208(1)$ \\
\hline${ }^{*} \operatorname{Pt}(2)^{n}$ & $-0.194(4)$ & $-0.1490(: 7)$ & $0.1627(18)$ & $0.064(8)$ \\
\hline$O(1)$ & $0.3055(7)$ & $0.2611(3)$ & $0.2437(3)$ & $0.0260(12)$ \\
\hline$N(I)$ & $0.0949(8)$ & $0.0823(4)$ & $0.2754(4)$ & $0.0267(17)$ \\
\hline$N(2)$ & $0.0662(7)$ & $0.0565(4)$ & $0.0819(4)$ & $0.0243(14)$ \\
\hline$C(1)$ & $0.2779(10)$ & $0.2329(.5)$ & $0.0324(4)$ & $0.035(2)$ \\
\hline $\mathrm{C}(3)$ & $0.1214(10)$ & $0.1013(5)$ & $0.3719(5)$ & $0.036(2)$ \\
\hline$C(4)$ & $0.0464(10)$ & $0.0477(6)$ & $0.447 !(6)$ & $0.039(3)$ \\
\hline$C(5)$ & $-0.0582(10)$ & $-0.0273(5)$ & $0.4214(5)$ & $0.033(2)$ \\
\hline$C(6)$ & $-0.0822(9)$ & $-0.0491(5)$ & $0.3209(5)$ & $0.030(2)$ \\
\hline$C(7)$ & $-0.0055(8)$ & $0.0065(5)$ & $0.2500(5)$ & $0.0237(19)$ \\
\hline $\mathrm{C}(8)$ & $-0.0154(7)$ & $-0.0100(4)$ & $0.1400(5)$ & $0.0240(19)$ \\
\hline$C(9)$ & $-0.1027(10)$ & $-0.0893(5)$ & $0.0983(6)$ & $0.038(2)$ \\
\hline$C(10)$ & $-0.1060(10)$ & $-0.1006(5)$ & $-0.0045(5)$ & $0.040(3)$ \\
\hline$C(11)$ & $-0.0247(10)$ & $-0.0344(6)$ & $-0.0630(6)$ & $0.040(3)$ \\
\hline$C(12)$ & $0.0635(9)$ & $0,0442(5)$ & $-0.0185(5)$ & $0.033(2)$ \\
\hline$C(13)$ & $0.4536(8)$ & $0.2626(5)$ & $0.2466(5)$ & $0.0237(19)$ \\
\hline$C(14)$ & $0.5389(8)$ & $0.1808(5)$ & $0.2089(5)$ & $0.0250(19)$ \\
\hline$C(15)$ & $0.6899(10)$ & $0.1852(5)$ & $0.2160(5)$ & $0.0330(19)$ \\
\hline$C(16)$ & $0.7565(10)$ & $0.2714(6)$ & $0.2591(5)$ & $0.042(3)$ \\
\hline$C(17)$ & $0.6742(9)$ & $0.3535(6)$ & $0.2952(5)$ & $0.042(2)$ \\
\hline$C(18)$ & $0.5220(8)$ & $0.3505(6)$ & $0.2886(5)$ & $0.031(2)$ \\
\hline
\end{tabular}

${ }^{a}=1 / 3$ of the trace of the orthogonalised $U$ tensor.

${ }^{b}$ The starred atom sites have populations of 0.985 and 0.015 for $\mathrm{P}(1)$ and Pit 2). respectively.

[13]. All calculations were performed on a DECstation $5000 / 133$. Final atomic coordinates and equivalent isotropic thermal parameters for $\mathbf{2}$ are listed in Table 3.

\section{Results and discussion}

\section{J. Preparation of methylplatinum aryloxide species}

The reaction of the dark red dimethylplatinum( II) complex $\left[\mathrm{Pt}(\mathrm{Me})_{2}(\mathrm{bpy})\right]$ with an excess of phenol in benzene provides a precipitate of a yellow solid complex that affords when washed with $\mathrm{Et}_{2} \mathrm{O}$ the new methylplatinum( II) aryloxide complex [Pt(Me)(OPh)(bpy)] (1) (Fig. I) as an orange solid in high yield. Based on the ' $H$ NMR data of the crude yellow solid in acetone- $\mathrm{d}_{6}$, which are similar to those of the palladium species $[\mathrm{Pd}(\mathrm{Me})(\mathrm{OPh})(\mathrm{bpy})] \cdot \mathrm{HOPh}$ [8a], we believe this material to be the $\mathrm{O}-\mathrm{H} \cdots \mathrm{O}$ hydrogenbonded phenol adduct $[\mathrm{Pt}(\mathrm{Me})(\mathrm{OPh})(\mathrm{bpy})] \cdot \mathrm{HOPh}$. However, our attempts to purify this intermediate complex by recrystallisation also led to formation of complex 1 . In the total reaction scheme for obtaining 1 (illustrated in Fig. 1) in which $\mathrm{CH}_{4}$ is the by-product, it can be seen that the excess phenol is an essential part of the reaction stoichiometry since it is required for the formation of the intermediate adduct. The reaction of $\left[\mathrm{Pt}(\mathrm{Me})_{2}(\mathrm{bpy})\right]$ with only one equivalent of $\mathrm{PhOH}$ afforded only $10 \%$ of 1 .

In the literature there are other examples of reactions in which a further equivalent of alcohol (accounting for $\mathrm{O}$
Table 3

Final coordinates and equivalent isotropic thermal parameters of the nonhydrogen atoms for 2

\begin{tabular}{|c|c|c|c|c|}
\hline Alom & $x$ & $y$ & $z$ & $U_{c 4}{ }^{a}\left(\AA^{2}\right)$ \\
\hline$P(1)$ & $0.22553(3)$ & $0.19181(3)$ & $0.44295(2)$ & $0.0146(1)$ \\
\hline I(1) & $-0.05009(5)$ & $0.19204(5)$ & $0.35727(3)$ & $0.0206(1)$ \\
\hline$O(1)$ & $0.2859(6)$ & $0.1702(5)$ & $0.3430(3)$ & $0.0235(16)$ \\
\hline$N(1)$ & $0.2330(7)$ & $0.3911(6)$ & $0.4324(3)$ & $0.0214(19)$ \\
\hline$N(2)$ & $0.1658(6)$ & $0.2464(6)$ & $0.5392(3)$ & $0.0155(17)$ \\
\hline$C(1)$ & $0.2284(9)$ & $-0.0001(7)$ & $0.4643(5)$ & $0.026(3)$ \\
\hline $\mathrm{C}(2)$ & $0.4266(7)$ & $0.1951(8)$ & $0.5063(4)$ & $0.0234(19)$ \\
\hline$C(3)$ & $0.2662(9)$ & $0.4567(8)$ & $0.3750(5)$ & $0.028(3)$ \\
\hline$C(4)$ & $0.2763(9)$ & $0.5864(8)$ & $0.3757(5)$ & $0.034(3)$ \\
\hline$C(5)$ & $0.2507(8)$ & $0.6525(7)$ & $0.4379(5)$ & $0.027(3)$ \\
\hline$C(6)$ & $0.2147(8)$ & $0.5856(8)$ & $0.4984(5)$ & $0.028(2)$ \\
\hline$C(7)$ & $0.2047(8)$ & $0.4550(7)$ & $0.49+0(4)$ & $0.021(2)$ \\
\hline$C(8)$ & $0.1662(7)$ & $0.3748(7)$ & $0.5533(4)$ & $0.018(2)$ \\
\hline$C(9)$ & $0.1314(8)$ & $0.4223(8)$ & $0.6181(4)$ & $0.025(2)$ \\
\hline$C(10)$ & $0.0937(9)$ & $0.3380(8)$ & $0.6697(5)$ & $0.031(3)$ \\
\hline$C(11)$ & $0.0880(9)$ & $0.2115(9)$ & $0.6546(5)$ & $0.031(3)$ \\
\hline$C(12)$ & $0.1255(8)$ & $0.1655(7)$ & $0.5894(4)$ & $0.021(2)$ \\
\hline$C(13)$ & $0.3664(7)$ & $0.0774(7)$ & $0.3255(4)$ & $0.017(2)$ \\
\hline$C(14)$ & $0.5055(8)$ & $0.0976(7)$ & $0.3327(4)$ & $0.022(2)$ \\
\hline$C(15)$ & $0.5847(8)$ & $0.0068(7)$ & $0.3069(4)$ & $0.021(2)$ \\
\hline$C(16)$ & $0.5259(8)$ & $-0.1069(7)$ & $0.2752(4)$ & $0.024(2)$ \\
\hline$C(17)$ & $0.3883(8)$ & $-0.1276(7)$ & $0.2691(4)$ & $0.0178(19)$ \\
\hline$C(18)$ & $0.3085(8)$ & $-0.0380(7)$ & $0.2939(4)$ & $0.020(2)$ \\
\hline
\end{tabular}

" $U_{\text {cal }}=1 / 3$ of the trace of the orthogonalised $U$ tenser.

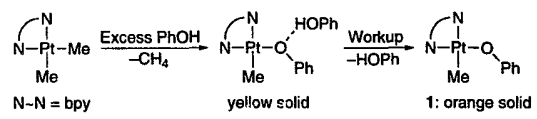

Fig. 1. Preparation of phenoxoplatinum( II) complex 1.

$\mathrm{H} \cdots \mathrm{O}$ hydrogen bonding) is actually needed to drive formation of a metal alkoxide species to completion. This type of procedure, starting from appropriate dimethylmetal complexes and fluorinated and aromatic alcohols $(\mathrm{ROH})$, has been successfully employed for preparation of complexes of general formula $\left[\mathrm{M}(\mathrm{Me})(\mathrm{OR})\left(\mathrm{L}_{2}\right)\right]$ in which the metal is palladium ( II) ( $\mathrm{L}=\mathrm{N}$-donor $[8]$ and $\mathrm{P}$-donor [ 5,6$]$ ligands) and platinum (II) (P-donor ligands $[5,6]$ ).

Interestingly, reaction of the $\mathrm{N}$-ligated platinum complex [ $\mathrm{Pt}(\mathrm{Me})_{2}($ bpy $\left.)\right]$ with two equivalents of $\left(\mathrm{CF}_{3}\right)_{2} \mathrm{CHOH}$, which is more acidic than phenol, in benzene at room temperature produces a black reaction mixture from which we could not isolate any recognisable aryloxide species. In contrast, the corresponding reaction of the platinum P-ligated species $\left[\mathrm{Pt}(\mathrm{Me})_{2}\left(\mathrm{PMe}_{3}\right)_{2}\right]$ with $\left(\mathrm{CF}_{3}\right)_{2} \mathrm{CHOH}$ has been shown to cleanly afford the alcohol adduct $[\mathrm{Pt}(\mathrm{Me})$ $\left.\left(\mathrm{OCH}\left(\mathrm{CF}_{3}\right)_{2}\right)\left(\mathrm{PMe}_{3}\right)_{2}\left|\cdot \mathrm{HOCH}\left(\mathrm{CF}_{3}\right)_{2}\right| 6 \mathrm{~d}\right\}$.

As illustrated in Fig. 2, reaction of the organoplatinum( II) aryloxide $[\mathrm{Pt}(\mathrm{Me})(\mathrm{OPh})(\mathrm{bpy})]$ (1) with iodomethane or benzyl bromide leads to the formation of the organoplatinum(IV) aryloxides $\left[\mathrm{Pt}(\mathrm{Me})_{2}(\mathrm{I})(\mathrm{OPh})(\right.$ bpy $\left.)\right]$ (2) and $\left[\mathrm{Pt}(\mathrm{Me})\left(\mathrm{CH}_{2} \mathrm{Ph}\right)(\mathrm{Br})(\mathrm{OPh})(\mathrm{bpy})\right](3)$, respectively. 

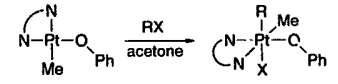

1: $N-N=$ bpy

2: $R=M_{\theta}, X=1$

3: $\mathrm{R}=\mathrm{CH}_{2} \mathrm{Ph}, \mathrm{X}=\mathrm{Br}$

Fig. 2. Preparation of phenoxoplatinum(IV) complexes 2 and 3.

These Pt(IV) complexes are yellow solids which have been characterised by elemental analysis, 'H NMR spectroscopy and for $\mathbf{2}$ by an X-ray crystal structure analysis. From these data it has been established that in general one isolates the product corresponding to trans addition of RX to the Pt(II) centre. However, in the case of Mel the product 2 dissolved in DMSO- $d_{6}$ affords NMR data (vide infra) consistent with the presence of both cis and trans addition isomers.

\subsection{Molecular structures of 1 and 2}

In order to study the geometrical differences between platinum (II) and (IV) aryloxides in the solid state, single crysta! $\mathrm{X}$-ray diffraction studies of $[\mathrm{Pt}(\mathrm{Me})(\mathrm{OPh})($ bpy $)](1)$ and $\left[\mathrm{Pt}(\mathrm{Me})_{2}(\mathrm{I})(\mathrm{OPh})(\right.$ bpy $\left.)\right](2)$ have been carried out. The

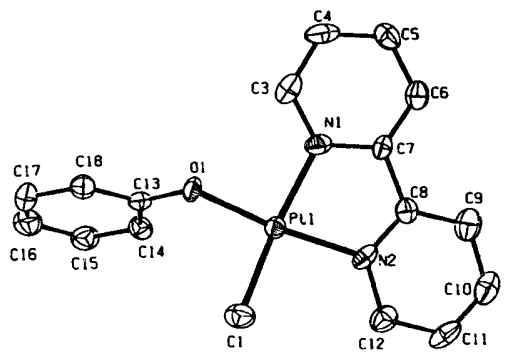

Fig. 3. ORTEP plot (50\% probability) of $\left|\mathrm{Pt}^{\mathrm{A}}(\mathrm{Me})(\mathrm{OPh})(\mathrm{bpy})\right|(1)$. $\mathrm{H}$ atoms are omitted for clarity.

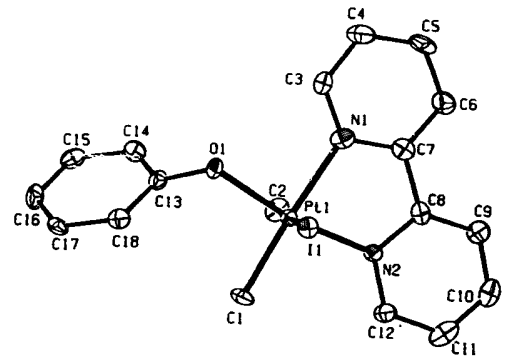

Fig. 4. ORTEP plot ( $50 \%$ probability) of $\left[\mathrm{Pt}^{\mathrm{NV}}(\mathrm{Me}),(\mathrm{I})(\mathrm{OPh})(\mathrm{bpy}), 12\right.$ ! $\mathbf{H}$ atoms are omitted for clarity.
Table 4

Selected hond distances $(A)$ and bond angles 1 ) for the phenoxide cirmplexes 1 and 2

\begin{tabular}{|c|c|c|}
\hline & 1 & 2 \\
\hline \multicolumn{3}{|l|}{ Distances (A) } \\
\hline Pl-O & $2001(5)$ & $2.01+(5)$ \\
\hline $\mathrm{Pl}-\mathrm{C}$ & $2.023(6)$ & $2.051+71$ \\
\hline $\mathrm{P}+\mathrm{N}(1)$ & $2.075(6)$ & $2.106(6)$ \\
\hline $\mathrm{Pl}-\mathrm{N}(2)$ & $1.992(6)$ & $2.018(6)$ \\
\hline $\mathrm{C}-\mathrm{O}$ & $1.358(10)$ & $1.349(9)$ \\
\hline $\mathrm{Pt}-1$ & & $2.8056(6)$ \\
\hline $\mathrm{Pl}-\mathrm{C}$ & & $2.052(7)$ \\
\hline \multicolumn{3}{|l|}{ Angles $\left({ }^{\circ}\right)$} \\
\hline $\mathrm{Pt}-\mathrm{O}-\mathrm{C}$ & 122.3141 & $127 .+(4)$ \\
\hline $\mathrm{N}-\mathrm{Pt}-\mathrm{N}$ & $79.8(2)$ & $79.412)$ \\
\hline $\mathrm{N}(1)-\mathrm{Pl}-\mathrm{C}$ & $175.8(3)$ & $174.5(3)$ \\
\hline $\mathrm{N}(2)-\mathrm{P} t-\mathrm{C}$ & $96.5(3)$ & $88.9(3)$ \\
\hline $\mathrm{N}(1)-P_{2}-O$ & $93.5(2)$ & 90.6121 \\
\hline $\mathrm{N}(2)-\mathrm{P}(-\mathrm{O}$ & 172.7121 & $170.0(2)$ \\
\hline \multicolumn{3}{|l|}{ I-Pn-C ${ }^{\star}$} \\
\hline I-Pl-O & & $89.68(17)$ \\
\hline
\end{tabular}

"Methyl positioned trans to I.

molecular structures of these complexes together with the adopted numbering schemes are shown in Figs. 3 and 4. respectively. Selected bond lengths and bond angles for 1 and 2 are collected in Table 4.

Complex 1 possesses an approximate square-planar coordination geometry with adjacent inter-ligand angles around the platinum centre falling in the range $79.8(2)-96.5(3)^{\circ}$. The platinum(IV) aryloxide complex 2 has an approximate octahedral coordination geometry with the $\mathrm{Me}$ and I situated trans to each other in apical positions. From examination of both structures it is apparent that there are only small geometrical differences between the corresponding $\mathrm{Pt}(\mathrm{Me})$. $(\mathrm{OPh})$ (bpy) entities in the platinum(II) and the platinum (IV) complexes. For example the Pt-Odistances in both complexes are almost identical (2.001 (5) (1) and 2.014(5) (2) $\AA$ ) and fall within the range of $\mathrm{Pt}-\mathrm{O}$ and $\mathrm{Pd}-\mathrm{O}$ distances found in related platinum $[6 \mathrm{~d} .7 \mathrm{a}]$ and palladium [6a,b.7b.8a] aryloxide complexes. The largest difference between 1 and 2 can be found in the Pt-O-C angles which are $122.3(4)$ and $127.4(4)^{\circ}$, respectively. This difference can be explained in terms of an increased metal-to-oxygen $d_{x}-p_{\pi}$ interaction for the platinum(IV) aryloxide complex due to the presence of two extra axial ligands. Furthermore. in both 1 and 2 the $\mathrm{Pt}-\mathrm{N}(1)$ bond trans to the methyl group $(2.075(6)$ and $2.106(6) \AA$. respectively) is considerably longer than the $\mathrm{Pt}-\mathrm{N}(2)$ bond cis to the methyl group $(1.992(5)$ and $2.018(6) \AA$. respectively), and this reflects the fact that the trans influence of the methyl ligand is larger than that of the phenoxide ligand.

\subsection{Solution studies of 2 and 3}

A 'H NMR spectrum in DMSO- $\mathrm{d}_{6}$ of the platinum(IV) complex $\left[\mathrm{Pt}(\mathrm{Me})\left(\mathrm{CH}_{2} \mathrm{Ph}\right)(\mathrm{Br})(\mathrm{OPh})(\right.$ bpy $\left.)\right]$ (3) shows 


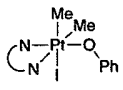

2a: Major

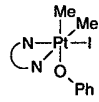

2b: Minor
Fig. 5 . Isomers of 2 ohtained from oxidative addition of Mel to 1

the presence of only one isomer. From the observed chemical shifts ( $\mathrm{Pt}-\mathrm{Me}$ and para-H-OPh) and coupling constants of $2 J(\mathrm{Pt}-\mathrm{Me}$ ) (in axial positions) a geometry can be deduced in which the benzyl and halide ligands are trans to each oiher (in axial positions) with the bidentate N.N'-coordinated bpy. the Me group and the O-bonded phenoxide occupying the meridional plane, i.e. 3 is a rams oxidative addition product. Van Asselt et al. reported similar NMR data for the single product obtained from the reaction of benzyl bromide with $[\mathrm{Pt}(\mathrm{Mc})(\mathrm{l})(p$ Tol-BIAN $)](p$ Tol-BIAN $=$ bis $(p$-tolylimino $)-$ acenaphthalene). i.e. the trans oxidative addition product $\left[\mathrm{Pt}(\mathrm{Me})\left(\mathrm{CH}_{2} \mathrm{Ph}\right)(\mathrm{Br})(\mathrm{I})(\mathrm{pTol}-\mathrm{BIAN})\right]$ [17]. In the ${ }^{\prime} \mathrm{H}$ NMR (DMSO- $d_{6}$ ) spectrum of the platinum(IV) complex $\left[\mathrm{Ft}(\mathrm{Me})_{2}(\mathrm{I})(\mathrm{OPh})(\mathrm{hpy})\right](2)$ there are two separate patterns in a $3: 2$ intensity ratio corresponding to two geometrical isomers. Since both isomers provide two different methyl group resonances one can conclude that these isumers are not those with either mutually trams methyl groups or with both methyl groups trans to the $\mathrm{N}$ donor atoms. Consequently. relative to the (bpy) Pt coordination plane the two isomers must both have one axial and one equatorial methyl group. and it is then the relative positioning of the phenoxide and the iodide ligands that discriminates the two forms: the two possible isomers are shown schematically in Fig. 5. Based on the literature 'H NMR shift data for the methyl groups in the complexes $\left[\mathrm{PtMe}_{3}\right.$ (bpy) $\left.\mathrm{X}\right](\mathrm{X}=\mathrm{Cl}, \mathrm{OPh})[18]$ we propose the major isomer (2a) to be the trans oxidative addition product or Mel (with the phenoxide ligand trans to one of the $\mathrm{N}$ atoms) and the minor isomer (2b) to be the cis oxidative addition product in which the phenoxide group is now in an axial position (with the iodide ligand trans to one of the $\mathrm{N}$ atoms ).

The $-\boldsymbol{J}(\mathrm{PtH})$ values for the $\mathrm{Pt}-\mathrm{Me}$ groups, which are in the range 69-74 Hz. are similar to those observed for organoplatinum(IV) complexes where the Me is positioned trans to an imine nitrogen [19].

One should note that in the above analysis of the solution NMR data of $\mathbf{1}$ and $\mathbf{2}$ we have not discussed ionic formulations in which DMSO functions as a neutral coordinating ligand in a complex cation with either halide or phenoxide as the counteranion. Since we have no direct evidence for such formulations, detailed treatment of this aspect is unwarranted in this short synthetic paper. However, we are aware of the importance of solvent effects in structure/reactivity relationships and in ongoing studies of metal complexes we are evaluating this topic more fully using additional techniques such as molecular modelling and solid state NMR spectroscopy.

\section{Concluding remarks}

The results in this paper illustrate that chelating $\mathrm{N}$-donor ligands are suitable for stabilising organoplatinum(II) and organoplatinum (IV) aryloxide complexes. The ready accessibility of these complexes show that unconventional combinations of 'soft' metal centres such as Pt(II) and' Pt(IV) with 'hard' ligands ( $\mathrm{RO}^{-}$) are easily achievable with appropriate supporting ligand arrays. Further studies are in progress to investigate the potential of these complexes in synthetic and catalytic processes.

\section{Supplementary material}

Complete tables of fractional coordinates of all atoms. bond distances and angles, anisotropic thermal parameters. and observed and calculated structure factors for $\mathbf{1}$ and $\mathbf{2}$ may be obtained from author A.L.S.

\section{Acknowledgements}

Sheil Research B.V. (G.M.K.) is gratefully thanked for financial support. The investigations were supporied in part (A.L.S. and N.V.) by the Netherlands Foundation of Chemical Research ( $\mathrm{SON}$ ) with financial aid ftom the Netherlands Organization for Scientific Research (NWO).

\section{References}

111 (a) R.C. Mehrotra. S.K. Agurwal and Y.P. Singh. Coord. Chem. Rev:, 68 (1985) 101: (b) C.3. Willis. Coorl. Chem. Rei., 88 (1988) 133; (c) H.E. Bryndza and W. Tam, Chem. Rev., 88 (1988) 1163.

I2I (a) J. Tsuji and I. Minami. Acce, Chem. Res., 20 (1987) 140: (b) H. Alper and B. Ali, J. Mol, Catal., 67 (1991) 29; (c) P. Barbaro, C. Bianchini, P. Frediani, A. Meli and F. Vizza. Inorg. Chem.. 3/ (1992) 1523: (d) A. Sen. M. Lin, L-C. Kao and A.C. Hutson, J. Am. Chem. Soc.. $11+(1992) 6385 ;$ (e) J.F. Carpentier. Y. Castanet. A. Mortreux and F. Petit.J. Organomet. Chem. 482 (199.4) 31: (f) E. Drent, J.A.M. van Broekhoven and M.J. Doyle. J. Organomet. Chem. 417 (1990) 235: (g) E. Drent. P. Arnoldy and P.H.M. Butzelaar, J. Organomet. Cheיט., 455 (1993) 247.

13: (a) J.M. Mayer, Comme'nts Inorg. Chem., 8 (1988) 125; (b) Evidence has been obtained for alkoxide $\pi$-donation (o) an Ir( III) centre: D.M. Lunder, E.B. Lobhovsky, W.E. Streib and K.G. Caullon, J. Am. Chem. Soc.. $113(1991) 1837$.

| 4 | (a) J.E. Bäckvall. E.E. Bjorkman, L. Petterson and R.J. Siegbahn. J. Am. Shem. Soc. $106(1984) 4364 ;$ (h) 107 (1985) 7265 .

|5| (a) Y-J. Kim. K. Osakada. K. Sugita, T. Yamamoto and A. Yamamoto, Organometallics, 7 (1988) 2182: (b) J.F. Hartwig. R.G. Bergman and R.A. Andersen. I. Am. Chem. Soc., II3 (1991) 6499: (c) R.D. Simpson and R.G. Bergman, Organometallics, 11 (1992) 4306; (d) S.K. Mandal. D.M. Ho and M. Orchin. Orgamometallics, 12 (1993) 1714; (e) J. Tsuji and T. Mandai, I. Organomet. Chem. 45/ (1993) 15: if) J.D. Smith. B.E. Hansson. J.S Merola and F.J. Waller. Orsanometallics, 22 (1993) $568 ;$ (g) I. Tóth and C.J. Elsevier. J. Chem. Soc., Chem. Commm. (1993) 529; (h) G. Vasapollo. L. 
Tonioli, G. Cavinato. F. Bigoli. M. Lanfranchi and M.A. Pellinghelli. J. Organomet. Chem.. 481 ( 1994) 173.

[6] (a) Y-J. Kim, K. Osakada, A. Takenaka and A. Yamamoto. J. Am. Chem. Soc., //2 (1990) 1096: (b) K. Osakada. K. Oshiro and A. Yamamoto, Organometallics, 10 (1991) 404: (c) C. Di Bugno. M. Pasquali. P. Leoni. P. Sahatino and D. Braga, Inorg. Chem., 28(1989) 1390: (d) K. Osakada, K-Y. Kim, and A. Yamamoto. J. Organomet. Chem.. 382 (1990) 303: (e) A.L. Seligson. R.L. Cowan and W.C. Trogler, Inorg. Chem., 30 (1991) 1096; (f) F. Ozawa. I. Yamagami and A. Yamamoto. J. Organomet. Chem., 473 (1994) 265: (g) K. Osakada. Y-J. Kim. M. Tanaka, S-I. Ishiguro and A. Yamamoto, Inorg. Chem.. 30 (1991) 197: (h) R.D. Simpson and R.G. Bergman. Inorg. Chem., 30 ( 1991 ) 3371.

|7| (a) P.L. Alsters, P.J. Baesjou. M.D. Janssen, H. Kooijman. A. Sicherer-Roetman. A.L. Spek and G. van Koten, Organometullics, II (1992) 4124: (b) G.M. Kapteijn. D.M. Grove, W.J.J. Smeets, A.L. Spek and G. van Koten. Inorg. Chim. Acta, 207 (1993) 131: (c) G.M. Kapteijn. D.M. Grove, H. Kooijman. W.J.J. Smeets, A.L. Spek and G. van Koten. Inorg. Chem., 35 (1996) 526; (d) C.A. Hunter. X.-J. Lu. G.M. Kapteijn and G, van Koten, J. Chem. Soc.. Faratay Trans.. 9/ (1995) 2009.

181 (a) G.M. Kapteijn. A. Dervisi, D.M. Grove, H. Kooijman, M.T. Lakin. A.L. Spek and G. van Koten. J. Am. Chem. Soc., 117 (1995) 10939 (b) G.M. Kapteijn. M.J. Verhoef, M.A.F.H. van den Broek. D.M.
Grove and G. van Koten, J. Organomet. Chem., 503 (1995) C26; (c) G.M. Kapteijn. A. Dervisi, M.J. Verhoef, M.A.F.J. van den Broek. D.M. Grove and G. van Koten.J. Organomer. Chem., $5 / 7$ (1996) 123: (d) Y.-J. Kim. J.-C. Choi and K. Osakada, J. Organomet. Chem.. 491 (1995) 97.

[9] P.K. Monaghan and R.J. Puddephatt. Organometallics. 3 ( 1984) +4. $110 \mid$ J.L. de Boer and A.J.M. Duisenherg. Acta Cnistallogr., Sect. A. in ( $1984, \mathrm{C} \$ 10$.

[11] A.L. Spek. J. Appl. Crvstullogr.. 21 (1988) 578.

[12] J. de Meulenaer and H. de Tompa. Acka Cnswallogr., 19 (1965) 1014.

[13] A.L. Spek. Acta Cnstallogr.. Sect. A. 46 (1940) C34.

1 14] P.T. Beurskens, G. Admiraal, G. Beurskens, W.P. Bosman. S. GarciaGranda. R.O. Gould. J.M.M. Snits and C. Snykalla. The DIRDIF program system. Tech. Rep. The Crystallography Laboratory. University of Nijmegen. Netherlands, 1992.

[15] G.M. Sheldrick, SHEL XL-93, program for crystal structure refinement. University of Götingen. Germany. 1993.

[16] A.J.C. Wilson (ed.). Internationa! Tables for Cnstallography. Vol. C. 1992. Kluwer, Dordrecht, Netherlands.

|17| R. van Asselt, E. Rijnberg and C.J. Elsevier, Organometallics. /3 (1994) 706 .

| $18 \mid$ J.E. Hux and R.J. Puddephatt. Inorg. Chim. Acta. 100 ( 1985 ) 1.

$119 \mid$ (a) D.E. Clegg. J.R. Hall and G.A. Swile. J. Organomet. Chem. t03 (1972) 38: ( b) J.D. Ruddick and B.L. Shaw, J. Chem. Soc. A. (1969) 2801 . 